Article

\title{
Anglican Moral Theology and Ecumenical Dialogue
}

\author{
Peter Sedgwick ${ }^{1,2}$ \\ 1 Honorary Research Associate, Cardiff University, Wales CF10 3AT, UK; peter.sedgwick2@btinternet.com \\ 2 Retired Principal, St. Michael's College, Cardiff CF5 2YJ, UK
}

Received: 18 August 2017; Accepted: 17 September 2017; Published: 20 September 2017

\begin{abstract}
This article argues that there has been conflict in Roman Catholic moral theology since the 1960s. This has overshadowed, but not prevented, ecumenical dialogue between the Roman Catholic and Anglican Communions, especially in ethics. Theologians from the Anglican tradition can help both the debate in Roman Catholic moral theology and the ecumenical impasse. The article examines the contributions of Richard Hooker, Jeremy Taylor, and Kenneth Kirk from 1600-1920, in the area of fundamental moral theology.
\end{abstract}

Keywords: moral theology; ecumenism; Anglican Communion; Roman Catholic Church; moral virtue; Imitation of Christ; moral judgements; moral absolutes; adiaphora/ $\alpha \delta\llcorner\alpha \dot{\phi о \rho \alpha}$

There are three arguments which I wish to advance in this article. The first is that Roman Catholic moral theology has been in a state of sustained engagement, and sometimes outright conflict, on the nature of moral theology, and the place of the human agent, since the 1960s. This is at the heart of Joseph Selling's recent and very valuable book, Reframing Catholic Theological Ethics (Selling 2016). It is this book which was honoured by a conference at Heythrop College, London, in January 2017, both for its own sake and as a way of exploring what the future direction of Catholic theological ethics (or moral theology) might be. I write as an Anglican moral theologian who has long been deeply influenced by Catholic moral theology. It gives me great pleasure to be included in this collection of essays, and to reflect on the ecumenical dialogue in moral theology. ${ }^{1}$ That could, of course, include dialogue with the Protestant and Orthodox traditions, but in this case I confine my article to the Anglican-Roman Catholic conversation in the area of ethics. The nature of theological method in ethics remains strongly disputed inside the Catholic moral community.

The second argument of this article is that this debate has overshadowed the search for ecumenical rapprochement in many places, but especially the acceptance of the report on moral theology entitled Life in Christ from the Anglican-Roman Catholic International Commission (ARCIC) (Anglican Consultative Council/Pontifical Council for Promoting Christian Unity 1994). ${ }^{2}$ The result of this

1 Due to personal circumstances I was unable to attend the conference. I am very grateful to the conference organisers that my paper for the conference has been included in the collection of articles from the conference.

2 The author has been an Anglican member of the Anglican-Roman Catholic International Commission (ARCIC III) from 2011-2017, but writes this article in a personal capacity only. At the time of writing (September 2017), the membership of the next phase of ARCIC III, which will begin in 2018, has yet to be announced. ARCIC III has profited from study of, and dialogue with, regional Anglican-Roman Catholic dialogues. The term 'regional' is chosen deliberately as it does not have ecclesiological implications, in the way for instance 'local' has, which refers to a diocese in Roman Catholic ecclesiology. One such regional dialogue studied by ARCIC III is the Anglican-Roman Catholic Theological Consultation in the USA (ARC USA), and their 2014 publication 'Ecclesiology and Moral Discernment: Seeking a Unified Moral Witness'.

The present article does not comment on the ARC USA document, but a longer article which included a greater consideration of ecumenical dialogue in moral theology would certainly do so. Likewise, because the focus of the present article is on the understanding of moral norms and judgments in Roman Catholic moral theology, especially the work of Selling, there is no discussion of how Taylor and Kirk's understanding of casuistry can be used to respond to the ARC USA document on the teaching charism of the church. The author of this article will publish (Sedgwick forthcoming) which will contain extensive treatment of casuistry in Taylor's works. 
has been a series of parallel discussions. There has been little, or almost no, discussion between the two communions on matters of gender and sexuality. What there has been is extensive discussions on social ethics, especially on the trafficking of peoples and global development.

Thirdly, there are contributions which Anglican ethics can bring both to the Catholic debate, and to ecumenism, in the area of moral norms and the nature of a moral absolute. I will look at three past Anglican theologians, Richard Hooker, Jeremy Taylor, and Kenneth Kirk. I will explore this contribution at length in this article.

It is generally accepted that the publication in 1993 of the Papal encyclical Veritatis Splendor was designed to end the dominance of a particular style of moral theology within the Roman Catholic Church. A Papal encyclical clearly has intrinsic authority, but the question is whether it has formulated the issue correctly, and also whether it reflects the guidance of the Spirit. Joseph Selling challenged the centrality of Veritatis Splendor for the very understanding of the nature of moral theology. He wrote in an article in the Heythrop Journal in 2010:

Ever since Veritatis Splendor laid claim to the idea that the principle factor in determining the morality of human activity was the choice of the object of a human act, I have been intrigued by the challenge that this presents to anyone who is persuaded by the idea that human activity can only be morally evaluated after all the relevant factors have been taken into account ... It is plausible because the entire tradition of the manuals of moral theology maintained that it is primarily the object of human activity, that behaviour which a person performs, that can be sufficient for determining whether or not a sin has been committed ... It is a narrow view of moral discernment because, expressed in this manner, it focuses exclusively upon behaviour without any consideration of the human person as committed to a life project (Selling 2010).

Veritatis Splendor itself is clear on the centrality of the place of the object for a proper construal of moral discernment and moral judgement:

If the object of the concrete action is not in harmony with the true good of the person, the choice of that action makes our will and ourselves morally evil, thus putting us in conflict with our ultimate end, the supreme good, God himself ... The primary and decisive element for moral judgment is the object of the human act, which establishes whether it is capable of being ordered to the good and to the ultimate end, which is God. ${ }^{3}$

You can contrast the argument of Veritatis Splendor with the entry on 'truthfulness' by Waldemar Molinski in the English translation of Karl Rahner's theological encyclopaedia Sacramentum Mundi, published in 1970. It showed how Catholic moral theology was changing, at least on the continent of Europe. Molinski wrote:

Truth is defined primarily as ontological, the basic intelligibility of all things, with God as the first truth. Further, God is held to be knowable but incomprehensible, while man is understood to be a being created in order to know and love God, who finds therefore his true self in being blessed by God and giving himself to God. The main task of an ethics of truth is then to remain as absolutely open for the truth in whatever guise man encounters it, and to unconditionally follow out the known truth in action. The ethics of truth will mainly take the form of an ethics of the disposition, insisting on the formal attitude. Hence an ethics of truth cannot do without reflection on one's personal consciousness and its implications (Molinski 1970).

This understanding of the relationship of the person and truth underlies the foundational shift in 20th century Catholic theology, from the 1950s onwards. It can be analysed into its different parts.

3 Veritatis Splendor, para. 73, 79. 
How does one measure moral truth? What is meant by the right realisation of the human person? In what way does the love of God, or more simply charity/caritas, establish and call the human person? How is this call related to becoming a member of the church that is the community of those who are disciples of Jesus Christ? None of these questions uses the methodology of 'the object of the human act', in the way the traditional manuals of moral theology had done, and which Veritatis Splendor was to revive. The questions mentioned above were to preoccupy those who became known as the revisionist moral theologians, and who were most prominent in the 1950s-1960s. Prominent members of this group were Bernard Haring, Josef Fuchs, Louis Janssens, and Alfons Auer. In turn these theologians mentored others, such as James Keenan. The development of moral theology in this direction also provoked a strong reaction, especially from traditional Thomists. This reaction gathered strength from the 1970s, and included those who maintained that their traditional interpretation of Thomas Aquinas was still correct (Russell Hittinger and Ralph McInerny); the new natural law school (Germain Grisez and John Finnis); and those theologians who became leaders of the Roman Catholic Church from the late 1970s (Karol Wojtyla, later Pope John Paul II, and Josef Ratzinger, later Pope Benedict XV). The debate between the followers of what came to be known as the revisionist school, or those who defined themselves as creating an autonomous ethics, and their critics dominated the second half of the 20th century within Catholic moral theology.

So, let me move to the second point of this article. At the same time that the possibility of a revisionist change in moral theology was being debated in Roman Catholic theology and inside the Roman Catholic Church, the Anglican-Roman Catholic International Commission (ARCIC) was being established. It was formally created in 1967, after a meeting between Archbishop Michael Ramsey and Pope Paul VI the previous year. One might have thought that ethics, or moral theology, would have been on the agenda for two reasons. First, as I have mentioned, there was a fundamental change in the nature of Catholic moral theology in the 1960s. Secondly, deep ethical questions divided the Anglican Communion and the Roman Catholic Church. Well before the issues of gender or of sexuality, which tended to rise to prominence in the 1970s and 80s, there was no agreement between the two communions on the nature of marriage, divorce, or-most controversially-contraception within marriage.

Ethics did not, however, appear properly in ARCIC for another 30 years, when Life in Christ was published in 1994. Its publication was preceded by Veritatis Splendor, which completely overshadowed it. This was for two reasons. Veritatis Splendor was a papal encyclical, and thus carried much greater weight than an ARCIC statement. Secondly, Veritatis Splendor was directly aimed at the long-running dispute between revisionist moral theologians and their critics within the Roman Catholic Church. Life in Christ does discuss absolute moral norms:

For example, a notable feature of established Roman Catholic moral teaching is its emphasis on the absoluteness of some demands of the moral law and the existence of certain prohibitions to which there are no exceptions. In these instances, what is prohibited is intrinsically disordered and therefore objectively wrong. Anglicans, on the other hand, while acknowledging the same ultimate values, are not persuaded that the laws as we apprehend them are necessarily absolute. In certain circumstances, they would argue, it might be right to incorporate contextual and pastoral considerations in the formulation of a moral law, on the grounds that fundamental moral values are better served if the law sometimes takes into account certain contingencies of nature and history and certain disorders of the human condition. ${ }^{4}$

This was not an approach that was compatible with Veritatis Splendor. Veritatis Splendor states clearly:

4 Life in Christ, para. 52. 
Reason attests that there are objects of the human act which are by their nature "incapable of being ordered" to God, because they radically contradict the good of the person made in his image. These are the acts which, in the Church's moral tradition, have been termed "intrinsically evil" (intrinsece malum): they are such always and per se, in other words, on account of their very object, and quite apart from the ulterior intentions of the one acting and the circumstances. ${ }^{5}$

Life in Christ has never been considered by the Congregation for the Doctrine of the Faith, and very few bishops' conferences have made statements either-one of the few was the US Catholic Bishops Conference, which called for clarification on the relationship between Life in Christ and Veritatis Splendor. However, the General Synod of the Church of England did finally debate it in 2009. There was an interesting contribution to the debate by the Archbishop of Canterbury Rowan Williams, under his own name (which is highly unusual for a Synod debate), which sets out some fairly far-reaching criticisms of Life in Christ, but also sees it as a document which could be built on. In particular, Rowan Williams looks back to the Anglican, and Protestant, tradition of the 16th and 17th century, beginning with Richard Hooker, but also extending into the 18th century, with Joseph Butler. I will come back to this. He wrote:

It is not only that Anglican theology developed a quite sophisticated tradition of casuistry (Life in Christ 1994, §45): in addition to this essentially pastoral element (exemplified by writers like Jeremy Taylor), there was much discussion of the concept of the laws of God, above all in Richard Hooker, and of the foundations of ethical coherence in the very concept of a creator, as in Bishop Joseph Butler's sermons and systematic works ... This lack of historical perspective explains (though it does not justify) the implication that notions of absolute moral law are somehow foreign to the Anglican ethos (Williams 2009). ${ }^{6}$

It is not clear, however, that Anglican theology has been quite so comfortable with the idea of 'absolute moral law', as we shall see when discussing Hooker and Kirk. It may well be that Life in Christ argued its case better than Archbishop Rowan had appreciated. It is clear that there are some actions which are always wrong for any human being (let alone a Christian) to commit, but the issue is how that moral judgement on the absolute wrongness of an action is formulated. I will return to this point in the final part of this article.

In terms of ecumenical dialogue, Archbishop Rowan Williams and Pope Benedict in 2008 finally agreed to restart the ARCIC dialogue, now called ARCIC III, and to focus on two areas. One is the relationship of the local and universal church. The other is to look again at moral decision-making, within an ecclesial context. In the preparatory document of 2008, it drew specific attention to the disagreements within the Anglican Communion. The challenge was therefore issued as to whether there could be an agreement about how Anglican methodology worked in ethics, and whether the Roman Catholic members of ARCIC III could find a way of common ground between that position and their own. ARCIC III began in 2011, and I am one of the Anglican moral theologians on the Commission. This article is, of course, only my personal opinion, and does not commit the Commission in any way.

Now, let me move to the third point of this article. How can Anglican moral theology assist the debate which Joseph Selling's book sets out so well? Selling's book contains a lengthy analysis of Aquinas' Summa Theolgiae, I-II, questions 1-21. This passage of the Summa concerns the structure of the moral event, including what is voluntary, and what Thomas calls 'circumstances'. Selling argues that in Thomas, 'the moral evaluation of human activity begins with the integrity of moral intention, which is subsequently followed by a consideration of behavioural options. Who one is, the moral character

5 Veritatis Splendor, para. 80.

6 General Synod article 24 June 2009. 
that the acting person exhibits, is by far more important than the sometimes clumsy, uninformed, or simply mistaken behavioural choices that we make' (Selling 2016, p. 82).

This emphasis on the virtues, which is central to Selling's argument, is also found in many Anglican theologians, especially the Caroline divines, such as Jeremy Taylor. Taylor, in The Great Exemplar, published in 1649 the first life of Christ in the English language. It was an innovation, because it combined a biography with an 'Imitation of Christ', as a book of practical devotion. It was also, and this is relevant to this article, a work on moral theology, where he wrote extensively on the virtues which Christ embodied, and which Christians should follow. The work is Christocentric, based on a strong doctrine of the Spirit, and sets out what a 'life in Christ' might look like. In that way it anticipates the ARCIC document Life in Christ. Taylor's work has a much longer full title, which opens with the words 'The Great Exemplar of Sanctity and Holy Life ... in the History of the Life and Death of the ever blessed Jesus Christ.' Taylor's section on the beatitudes includes a consideration of the virtues, including prudence: 'It will require our prudence and care to preserve the simplicity of our purposes and humility of our spirit' (Taylor 1822-1828; McAdoo 1994). The relevance to Selling's emphasis on virtue ethics in his book is clear.

The consideration of moral absolutes by the 16th century Anglican theologian Richard Hooker is also instructive here. Hooker's philosophy of action is opposed to soft and hard determinism, and he believes that the cause of human error in action and belief-formation is because one of the mental faculties has failed to function correctly (Voak 2003). ${ }^{7}$ Hooker is different from both Aquinas and Calvin in accepting both liberty of spontaneity and liberty of indifference. Hooker has his own conception of how human beings are able to reason, desire, and imagine. Hooker had a strong commitment to free will both in his discussion of the relationship of will and reason in his philosophy of mind, and in his discussion of sin and wrong action in his philosophy of action (Voak 2003, p. 41). Liberty of spontaneity concerns human wanting. We are free when we act only if we act because we wish to act in this way. That is compatible with determinism: we may have no ability not to act, but we wish to act anyway, because of the attraction of the good on what is created. God, who is perfect goodness, attracts human action. So we are free in our action, even if we may rebel against this attraction of desire. That in essence is the argument of Aquinas. The will for Aquinas was a passive power, and it is the intellect which compares possibilities. Will is therefore a rational appetite or desire in Aquinas. ${ }^{8}$ Aquinas saw will as only the material cause of action, while reason is the formal cause (Voak 2003, p. 33). ${ }^{9}$ Liberty of spontaneity is compatible with causal determinism, and was a belief held both by Aquinas and Calvin.

Hooker, however, is concerned first with the freedom of choice, before he relates will and reason. It is therefore our experience of choice, or of free will, which is metaphysically the determining factor for Hooker's understanding of the philosophy of mind. This is a voluntarist, or in this case Scotist, understanding of the will as freedom of choice. It involves a commitment to liberty of indifference. We are free only if it is in our power not to do it. Hooker argued that the will is a faculty of intellectual desire and concentrates in Book 1, chapter 7 of the Lawes on the freedom of this desire. Hooker begins his argument by discussing the practical reason, then moves on to desire, or the goodness which we conceive is best for us, and then finally asserts the complete freedom of this desire. What is crucial is that 'we so like and desire it'. Choice is the ability 'to will one thing before another'. ${ }^{10}$ Will, choice, and desire appear to be synonymous. Desire assumes that one thing is to be preferred before another, and since willing and choice are both acts of desire, then they are identical. The object of desire is that good which is apprehended by reason. Hooker thus has a libertarian definition of will, and contrasts humanity with the action of fire, which has no choice in its actions. 'Will in things tending towards

\footnotetext{
(Voak 2003) Henceforward 'Voak'.

S.Th I.85.2.ad3: 'reason relates to many things ... and so will can be moved by any of many things.'

Aquinas, S.Th, I.II.13.1.

(Hooker 1977) Henceforward 'Lawes'. Voak, Richard Hooker, p. 51.
} 
any end is termed choice. ${ }^{11}$ Even with the action of reason, and even with the attraction of God as perfect goodness on the reason, nevertheless 'the truth is, that such actions in men having attained to the use of reason are voluntary'. ${ }^{12}$ Intellectual desire and freedom of choice are therefore integral to Hooker's definition of will.

So. if we are free in our choosing, how is our choice guided? Like Aquinas, Hooker felt that the study of scripture was something which required careful diligence and much training, but when interpreted appropriately could yield clear and normative guidance. There are matters which can seem 'more obscure, more intricate and hard to be judged of', and so what is needed is long study by theologians-those who 'spende their whole time in the studie of things divine, to the end that in these more doubtfull cases their understanding might be a light to direct others' (Joyce 2012) ${ }^{13}$ In discussing whether the 'sentence' of reason is mandatory, permissive, or admonitory, Hooker is clear that reason operates 'setting downe what is good to be done'. ${ }^{14}$

Mandatory forms of the sentence of reason concern action which 'in it selfe is absolutely good or evill', such as the biblical example cited by Hooker from Genesis 39:9, about Joseph, when his master's wife invited him to commit adultery. ${ }^{15}$ In this case, 'where the comparison doth stande altogether betweene doing and not doing of one thing which in it selfe is absolutely good or evill', then the choice of actions at this point as a choice between 'the one evill, the other good simply'. ${ }^{16}$ It is clear that Hooker accepts the existence of moral absolutes as part of the law of reason, which can be known by everyone. However, this is not premised on the idea of an intrinsically evil act, but because of the absolute nature of the end chosen, which in Genesis 39 is the desire of one person to commit adultery with another. No doubt issues of power, control, and ethnic identity were also involved. For example, Joseph was a Hebrew servant. His master's wife was an Egyptian. Hooker therefore accepts that there are moral absolutes, but (and this is important) he does not frame this discussion in terms of absolute moral law. It is 'the comparison (of the) doing of one thing which in itself is absolutely good or evil'. Two points should be noted. First, a moral judgement must be made for there to be moral absolutes. Secondly, the judgement is about an action ('between doing and not doing of one thing') and not about an absolute moral law. When Hooker talks of moral law, it is in terms of 'the lawe of reason', which 'is that which men by discourse of naturall reason have rightly found out'. ${ }^{17}$

One final point in Hooker should be noted. Actions neither required nor forbidden by the moral law are called morally indifferent. Reason in matters of $\alpha \dot{\alpha} \mathbf{i} \phi o \rho \alpha$ can only make out a probable case, and Hooker leaves the conclusion of the argument as a matter for the individual Christian conscience. That gives a freedom to consider the possibility of change in matters of order and polity. However, the conscience is always guided by the voice of the Church. Hooker is emphatically not a proto-liberal. Hooker is a conservative, and in most things he feels that longevity carries the benefit of presumption. But just as sins of malice can be caused by vicious customs, especially if they are long established, so too can customs become harmful, even if they were good when established. 'How sometimes that hath done great good, which afterwards when time hath changed the ancient course of things, doth growe to be either very hurtfull, or not so greatly profitable and necessary. ${ }^{18}$

The answer is then an appeal to the authority of the Church. 'The Church being a body which dyeth not hath always power, as occasion requireth, no less to ordeine that which never was, then to ratifie what hath bene before ... The Church hath authoritie to establish that for an order at one tyme, which at another it maie abolish, and in both it doe well ... Lawes touching matters of order

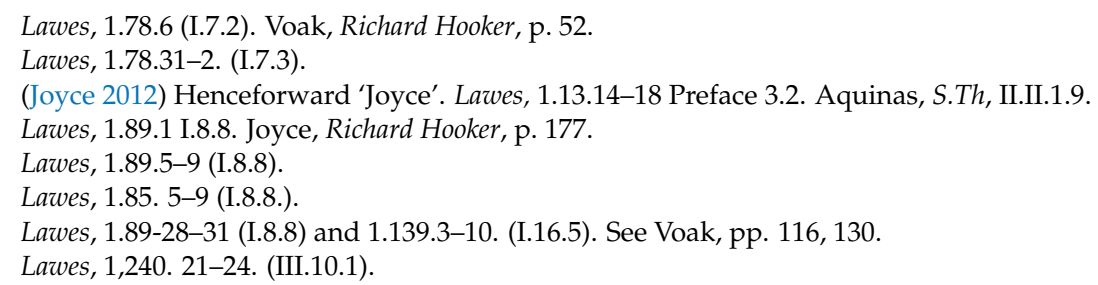


are changeable, by the power of the Church; articles concerning doctrine not so.' ${ }^{\prime 19}$ The mere fact that a law is given in Scripture proves nothing for him. The crucial question is whether that law should remain in force. Some Jewish ceremonial laws were abolished by the priesthood of Christ; others may need to be changed. So Hooker himself displays his paradox. 'God never ordained anything that could be bettered. Yet many things he hath that have been changed and that for the better. That which succeeds as better now when change is required had been worse when that which now is changed was instituted. $^{20}$

This is important not only as a challenge to Veritatis Splendor, but also in ecumenical dialogue. As an Anglican moral theologian on the Anglican Roman Catholic International Commission, I struggle with the idea of intrinsically evil acts, and this would echo earlier Anglican writers. Bishop Kenneth Kirk, for instance, who was the leading English Anglican ethicist in the early 20th century, argued for 'immutable principles of right and wrong which may be called the perfect law of God', but 'secondary principles are left to man to interpret' (Kirk 1927). ${ }^{21}$ These absolutes are predicated of principles, not actions, and the application of authoritative principles is complex and difficult. Kirk was skeptical of ecclesiastical claims to unquestioning obedience, even though he was Bishop of Oxford. 'The Church of this century or that may make a similar claim, and once again the principle on whose behalf the claim is authoritative for those who made it. But none of these factors guarantee eternal immutability.' Kirk accepted that there was 'truth as it exists in the mind of God' which is 'the immutable divine law.' Beyond that there were only variables, and secondary principles of divine law would merge into human law in the ecclesiastical sphere (Kirk 1927, pp. 77-78). This required careful interpretation.

So, let me conclude this article. I have argued three things. First, I agree with Professor Selling that there is indeed an impasse in Roman Catholic methodology in moral theology. Veritatis Splendor certainly argues that the decision of the Church's Magisterium 'is preceded and accompanied by the work of interpretation and formulation characteristic of the reason of individual believers and of theological reflection'. ${ }^{22}$ However, Peter Baelz (one of the consultants to Life in Christ, and a prominent English, Anglican ethicist) pointed out that for this to be true, far more weight needed to be given to the reality of participation in the constitution of the Church as is given to the reality of hierarchy (Baelz 1994, p. 90). Baelz also points out the difficulty of formulating a logically valid status for absolute negative moral precepts, since it is impossible to formulate moral precepts in a way that covers all possible future contingencies. This is Kirk's point, and Baelz amplifies it by arguing that actions which are 'always morally forbidden', or intrinsically wrong, are transparently so to humankind. 'Both the claim to discernment and the claim to demonstration are found wanting. ${ }^{23}$ This is also Hooker's argument in the Lawes. Divine law can certainly be of aid to the search of human reason, but nevertheless human nature finds out which human actions are 'to be for ever bound unto' as actions which are wrong. ${ }^{24}$

Secondly, this impasse inside the Roman Catholic Church has gravely impeded Anglican- Roman Catholic ecumenical dialogue. As this dialogue continues afresh at the present (and I write as an individual here, not from the standpoint of the Anglican-Roman Catholic International Commission), the contribution of Life in Christ as a document must be recognised and built on. It is difficult to do so if the object of the action is at the centre of the moral judgement, as the way of preserving its objectivity and realism. This is the point made by such distinguished moral theologians as Servais Pinckaers, but it is certainly not a way of arguing in moral theology that is consonant with ecumenical dialogue

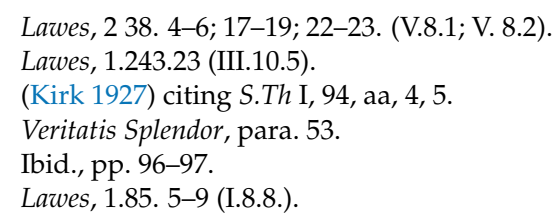


(Pinckaers 1999, p. 58). Moral judgements can be both objective and realist in terms of other moral theories, as most Anglican moral theologians would argue. It is a sleight of hand to equate objectivity and realism, which are indeed desirable attributes of a moral judgement, with placing all the emphasis on the object of the action. Evaluating behaviour is not the only way to ensure moral objectivity, but one would not think so from reading Veritatis Splendor, or indeed Pinckaers defense of the encyclical. There has to be recognition of other ways of proceeding if ecumenical dialogue in moral theology is to mean anything. That is why ecumenism reached such an impasse in moral theology from 1993 to the present, despite the publication of Life in Christ. That document was simply side-lined, to the detriment of ecumenism.

Thirdly, I have looked at two Anglicans, one from the 16th and one from the early 20th century, to resolve the difficulty of absolute moral norms. Neither Hooker nor Kirk wished to deny the gravity of moral evil, and both stressed the severity of sin. Kirk, in fact, struggled to allow artificial contraception as anything but a possibility in exceptional circumstances, until his death in 1954. It would be impossible to regard Hooker or Kirk as theological liberals, to use a deliberately crude analogy. What they do emphasise, however, is that moral theology does not begin with moral absolutes, nor with regarding certain moral 'objects' (or actions) as intrinsically evil. I have tried to show how much richer Hooker's thought is than this. If Roman Catholic moral theology is to continue its vigorous debate in the 21st century, as I am sure it will, then attention to Anglican moral theology will be of great help in this endeavour. Joseph Selling has long been an outstanding contributor to Roman Catholic moral theology, and his valuable book, which the Heythrop Conference recognised, will aid that debate. I hope that my ecumenical suggestion is of assistance to Professor Selling's project, which may be called the 'Reframing of Catholic Theological Ethics'.

Conflicts of Interest: The author declares no conflict of interest.

\section{References}

Anglican Consultative Council/Pontifical Council for Promoting Christian Unity. 1994. Life in Christ. Morals, Communion and the Church. London: Church House Publishing/Catholic Truth Society.

Baelz, Peter. 1994. An Ecumenical Perspective. In Veritatis Splendor - A Response. Edited by Charles Yeats. Norwich: Canterbury Press.

Hooker, Richard. 1977. Lawes of Ecclesiastical Polity, Folger Library Edition. 1.78.1. (I.7.2) ed. Cambridge: The Belknap Press of Harvard University Press.

Joyce, Alison Jane. 2012. Richard Hooker and Anglican Moral Theology. Oxford: Oxford University Press.

Kirk, Kenneth. 1927. Conscience and its Problems. London: Longmans, Green and Co.

McAdoo, Henry. 1994. First of Its Kind: Jeremy Taylor's Life of Christ. Norwich: Canterbury Press.

Molinski, Waldemar. 1970. Truthfulness. In Sacramentum Mundi: An Encyclopaedia of Theology. London: Burns and Oates.

Pinckaers, S. 1999. An encyclical for the future: Veritatis Splendor. In Veritatis Splendor and the Renewal of Moral Theology. Edited by J. Augustine Dinoia. Huntington: Our Sunday Visitor.

Sedgwick, Peter. Forthcoming. The Origins of Anglican Moral Theology. Leiden: Brill.

Selling, Joseph. 2010. Looking towards the end: Revisiting Aquinas' teleological ethics. Heythrop Journal 51: 388-400. [CrossRef]

Selling, Joseph. 2016. Reframing Catholic Theological Ethics. Oxford: Oxford University Press.

Taylor, Jeremy. 1822-1828. The Great Exemplar in Taylor, Jeremy Works. Edited by Heber. London: Longmans, vol. II. Voak, Nigel. 2003. Richard Hooker and Reformed Theology: A Study of Reason, Will and Grace. Oxford: Oxford University Press.

Williams, Rowan. 2009. Life in Christ. London: Church House Publishing.

(C) 2017 by the author. Licensee MDPI, Basel, Switzerland. This article is an open access article distributed under the terms and conditions of the Creative Commons Attribution (CC BY) license (http:// creativecommons.org/licenses/by/4.0/). 